\title{
Financial contracting and re-rating experience, the cases of make whole, claw back and other wise ordinary callable bonds
}

\author{
Frank S. Skinner ${ }^{1}$, \\ University of Surrey \\ Dimitrios Gounopoulos
}

University of Surrey

\begin{abstract}
The literature states that ordinary callable bonds help resolve several agency issues while make whole and claw back bonds are supposed to resolve the underinvestment problem. The justification for refinements of the classic call option is not clear as firstly, the classic call option seems able to handle the underinvestment problem anyway and secondly, the existing empirical evidence does not examine whether make whole and claw back bondholders actually benefit from the resolution of agency problems. We find evidence that firms' do select make whole and claw back provisions to better confront the underinvestment problem for below investment grade bonds.
\end{abstract}

Keywords: Callable bonds, Claw back call provisions, whole make call provisions

JEL classification: G24, G32, G38, K12, K22

\footnotetext{
${ }^{1}$ Frank Skinner is Professor of Finance at the University of Surrey School of Management, University of Surrey, Guildford, Surrey, GU2 7XH, United Kingdom e-mail: f.skinner@surrey.ac.uk, tel +44 148368 6364, Fax +44 148 3686346. Dimitrios Gounopoulos is Lecturer of Finance at the University of Surrey.

We thank Panayiotis Andreou, Simone Varrotto and Peggy Huang for many helpful comments. We gratefully acknowledge Campbell Harvey. We would like to thank meeting participants of the Multinational Finance Association 2009, the Financial Management Association 2009 and European Financial Management Association 2009 for helpful comments on earlier versions of this paper. Any errors are the authors' responsibility. Corresponding Author: Frank Skinner.
} 
Financial contracting and re-rating experience, the cases of make whole, claw back and other wise ordinary callable bonds

\section{Introduction}

In recent years many bond indenture agreements include two new provisions, the make whole and the claw back provision that refine the circumstances upon which a bond can be redeemed prior to maturity. The make whole call price represents the present value of all coupon and principal repayments. The call price is determined by a discount rate set as the yield on a similar maturity Treasury bond plus a fixed spread. This implies that the firm has little incentive to refinance its debt due to a fall in the level of interest rates. Similarly, the claw back provision reduces the incentive to refinance in order to save on interest costs by allowing the firm to call debt only from the proceeds of an equity issue. We seek to understand the purpose of these new refinements of the ordinary call provision.

Goyal et al. (1998) and Nayar and Stock (2008) find evidence that make whole and claw back bonds are justified by alleviating agency problems such as the underinvestment problem that is often present for firms with risky prospects and debt in its capital structure. Yet while this work shows that stockholders can benefit from the use of these provision it is not clear whether bondholders do. For example Nayar and Stock (2008) find that the stock of firms that issue make whole bonds enjoy a significant favorable price reaction to the issue, have superior post issue returns and analysts forecast higher post issue growth for firms issuing make whole bonds. Yet the literature is silent on whether bondholders benefit.

The situation is made more puzzling because Banko and Zhou (2010) find that the classic call option is used to resolve a combination of asymmetric information and underinvestment problems. Therefore the justification for refinements of the classic call option is not clear as firstly, the classic call option seems able to handle the underinvestment problem anyway and secondly, the 
existing empirical evidence does not examine whether make whole and claw back bondholders actually benefit from the resolution of agency problems.

This work is of interest because we now understand that if a bond contract term appears to benefit shareholders ex post, it can well be the case that bondholders can anticipate these benefits and expropriate them in the initial terms of the bond contract. For example, as it is well understood from Kraus (1973) that potential interest cost savings is not a valid reason for callable bonds since any potential expropriation of wealth by re-issuing lower coupon bonds is anticipated by bondholders through higher initial coupon rates and call prices. One question that we address is whether make whole and claw back provisions genuinely improve callable bond contracts by better handling the underinvestment problem or can they be seen as an attempt to exploit bondholders in a zero sum game? Our insight is that if the make whole and claw back bonds represent a genuine improvement in dealing with the underinvestment problem then the subsequent re-rating of make whole and claw back bonds should be dominated by more upgrades and/or less downgrades than ordinary callable bonds. If the zero sum game explanation holds true, then subsequent re-rating experience should be no different, or indeed worse, that ordinary callable bonds so there is no evident reason to refine the classic call option contract.

The underinvestment problem occurs because positive NPV projects look too risky for debt holders. While the firm knows their projects are "good" they have difficulty in convincing skeptical bondholders. As a result the firm must pay higher interest costs than they "should" given the quality of their projects. If the projects prove themselves bondholder's benefit at the expense of stockholders as they will continue to enjoy high coupon rates even though risk is now revealed to be modest. This reduces the benefits that flows to the shareholders and weakens the inventive to invest. Meanwhile the asymmetric information problem occurs because the firm is unable to reveal the value of future growth opportunities without moral hazard so bondholders undervalue the firm. 
To resolve the underinvestment problem the firm could issue a callable bond. When the quality of the projects is revealed the firm can exercise the call feature thereby replacing the high coupon callable bond with a lower coupon bond. If in fact make whole and claw back bonds are used by firms to resolve the underinvestment problem then the firm's stock price and growth prospects should improve (Nayar and Stock (2008)), the issuing firm's credit risk should decrease and the ratings of make whole and claw back bonds should increase. If in fact make whole and claw back bond re-rating experience is superior to ordinary callable bond re-rating experience then this indicates that they are justified by refining the classic call option contract to better handle the underinvestment problems faced by firms that use them.

An idea of the complexity of the issue can be gleaned from Table 1 that reports the salient quantitative details of the call provisions of our sample. ${ }^{2}$ Table 1 show that the "price" for invoking a call provision of any type generally increases as the credit rating decreases. Table 1 also highlights that the call protection period for ordinary calls is substantial, approximately three and a half years on average, whereas for make whole bonds it is virtually non existent, usually less than three months. Meanwhile the claw back provision is operative upon issue. Clearly investors are offered much more "protection" from ordinary call provisions than they are for claw back and make whole provisions. ${ }^{3}$ On the other hand controlling for credit rating the average call price for ordinary call provisions is modest whereas substantial premiums are offered for the exercise of a make whole or a claw back provision. Therefore it is unclear if bondholders' view claw back and make whole bond provisions more favorably than ordinary call provisions because while evidently claw back and make whole provisions require a shorter protection period, they do require more compensation if exercised.

\footnotetext{
${ }^{2}$ The sample size of Table I is often less than the corresponding sample sizes in Tables II, III and IV as detailed later because details of some of the call provisions are missing from the Mergent ${ }^{\mathrm{TM}}$ fixed income database.

${ }^{3}$ Interestingly this hints at the circumstances upon which the claw back and make whole bonds can be better suited to resolve the underinvestment problem. A firm that has an undervalued project that will shortly be revealed as good when the first results are in would desire a type of call provision than can be immediately exercised.
} 
$<<$ Table 1 about here $>>$

We find interesting differences in the use of make whole and claw back provision bonds. Make whole bonds are used for all credit grades whereas claw back bonds are used almost exclusively for bonds rated below investment grade. Moreover ordinary callable bonds are most frequently issued by financial firms whereas make whole and claw back bonds are most frequently issued by industrial firms. Importantly, after applying controls for credit rating, industry, foreign status, bond covenants (put, sinking fund, security level and conversion features), private placement and exchange listing status, maturity, bond market conditions and issuing firm characteristics (size, leverage, liquidity, growth and profitability), we find that below investment grade make whole and claw back bonds have a significantly higher likelihood to upgrade and below investment grade claw back bonds have a significantly lower likelihood to downgrade than ordinary callable bonds. In other words, we find evidence that make whole and claw back call provisions genuinely confront the underinvestment problem better than ordinary callable bonds for the rating grades where agency problems tend to be most sever.

\section{Agency Cost Explanations of Callable Bonds}

The literature suggests that three types of call provisions can resolve the underinvestment problem, the classic call, make whole and claw back call provisions. A classical call option empowers the issuer to take advantage of bondholders by repaying the debt in advance when market yields decline. When interest rates decrease, the classical call option settlement amount is less than what the fair value of a debt would have been absent the call option. Following Kraus (1973) finance has largely rejected interest cost savings as an explanation for call provisions since in an efficient market gains to shareholders via refinancing at lower interest rates would be anticipated and 
expropriated by bondholders in the terms of the initial call provision. Recently Banko and Zhou (2010) find that ordinary call provisions are useful for hedging interest rate uncertainty but only for investment grade bonds.

Instead, in the main, call provisions are supposed to exist because of agency problems such as the underinvestment, asymmetric information and asset substitution problems. More to the point, to resolve the underinvestment problem, classic callable bonds can be called once the value of the firm's projects is revealed. Bodie and Taggart (1978) state that even when interest rates are such that bondholders are indifferent between callable and non-callable bonds, the firm's risky projects can give shareholders a definite preference for callable bonds. If this explanation holds then all else equal callable bonds should experience more upgrade and less downgrade credit events as the good results of the firm's projects are subsequently revealed.

Thatcher (1985), Kish and Livingston (1992), Boreiko and Lombardo (2008), Jorion and Zhang (2010) and Eisdorfer (2011) all suggest that agency explanations as a whole can explain the use of call provisions. However, Crabbe and Helwege (1994) find that the confounding effects of maturity, default risk and varying trends in the popularity of call provisions make it difficult to empirically verify if any of the specific agency problems can explain the use of ordinary call provisions. Banko and Zhou (2010) reply to Crabbe and Helwege (1994) finding that ordinary call provisions are useful in dealing with a combination of underinvestment and asymmetric information problems rather than each agency problem in isolation. Additionally several authors provide explanations why firms can employ a sub optimal call policy. Mauer (1993) finds that firms can delay calls due to transactions costs, Longstaff and Tuckman (1994) and Mitto and Zhang (2010) explains that wealth transfers resulting from temporary capital structure changes can cause a sub optimal delay and King and Mauer (2000) observe that firms can employ a sub-optimal call policy for a variety of reasons. In any event Crabbe and Helwege (1994) do not find any evidence that callable bonds reduce the underinvestment problem alone. Specifically when controlling for credit 
risk, maturity and trends in the use of call provisions they find that callable bonds are no more likely to upgrade or downgrade than non-callable bonds.

With a make-whole call provision, the call price is not determined by a price schedule. Instead as Collin-Dufresne and Goldstein (2001), Collin-Dufresne et al. (2001) and Gottesman and Roberts (2007) note make whole provisions have a call price determined by discounting the bond's remaining contractual cash flows at a specified spread over a similar maturity Treasury rate. Therefore the call price floats inversely with Treasury rates. If exercised, the make-whole call price is calculated as the maximum of par value or the present value of the bond's remaining payments. A primary benefit of the make-whole call provision relative to the classical call provision is that the floating call price virtually eliminates the incentive for the firm to call when interest rates decrease. Thus, make whole bondholders face little risk that their income can be expropriated due to adverse interest rate movements.

Make-whole call provisions have become quite common in corporate debt over the past ten years. ${ }^{4}$ Mann and Powers (2003b) suggest that the make-whole call is useful for firms that anticipate a need for financial flexibility without any dependence on low economy-wide interest rates. Powers and Tsyplakov (2004) use a structural model to examine whether make-whole call provisions are fairly priced initially and conclude that make-whole call provisions are too expensive for the benefits that they provide. Power and Tsyplakov (2008) report that make-whole call provisions are significantly overpriced on average across a 10-year sample but incremental yields are decreasing in the later part of the sample.

Nayer and Stock (2008) find clear evidence that stockholders do in fact benefit from issues of make whole bonds and suggest that make whole bonds alleviate agency costs without the use of expensive ordinary call provisions. Survey evidence in Mann and Powers (2003b) and Powers and Sarkar (2006) find that corporate executives believe make-whole call provisions offer tangible

\footnotetext{
${ }^{4}$ Approximately 20\% of the issues in the Merrill Lynch 1-5 Year Government Corporate Index have make-whole call provision.
} 
benefits to the firm in the form of increased financial flexibility. Thus, firms are willing to pay a premium in order to incorporate make-whole call provisions. However, Mann and Powers (2003a) and Power and Tsyplakov (2004) see little opportunity for arbitrage opportunities due to the incompleteness of the corporate bond market. Without arbitrage opportunities, there is no obvious mechanism that will drive down the incremental offer yield of make-whole call provisions.

Make whole provisions can alleviate the underinvestment problem because it separates the incentive to call a bond to achieve interest cost savings from calling a bond to avoid the underinvestment problem. Specifically the firm can call the entire bond issue only at a call price determined by a yield that is set at a predetermined spread above a similar maturity treasury yield. This means that as interest rates decrease, the call price increases so there is little room for coupon cost savings due to interest rate changes. The firm is free to take on a risky project in the assurance that if the project subsequently proves itself, the firm can call the bond at prices consistent with the general level of interest rates and so avoid expropriation of the benefits of the now proven project by the bondholders. Once the quality of the project is revealed, stock returns improve and stock analysts growth estimates are upgraded (Nayar and Stock 2008) so it is not unreasonable to suspect that rating agencies would upgrade the credit quality of the firm's bonds. Accordingly make whole bonds should experience unusually positive re-rating experience if firms use them to fund risk projects subject to the underinvestment problem.

According to Fridson (1993) claw back provisions appeared in high yield offerings in 1992. These clauses allow issuers to partially call a bond issue with capital raised from equity financings despite ordinary call limitations. Bonds with claw back provisions are also thought to alleviate the under investment problem. Generally, asymmetric information problems become less severe when a new project commences via equity investment. This means the investment decision can cause a wealth transfer from shareholders to bondholders as bondholders benefit from a reduction in credit risk but still enjoy a high coupon rate set when information asymmetries were high. This can lead to 
the underinvestment problem because managers will wish to avoid this wealth transfer and so will be reluctant to accept profitable projects requiring new equity financing. Claw back provisions make it possible for issuers to mitigate wealth transfers that result from a reduction in information asymmetries surrounding equity offerings as the firm can repurchase a portion of old high coupon bond issues at relatively low prices. Therefore bonds that contain claw back call provisions should on average experience unusually good re-rating experience as firms with claw back provisions should issue equity, thereby reducing reliance of debt in the firms' capital structure, to finance valuable projects.

Goyal et al. (1998) argue that claw back provisions are designed to soften problems of underinvestment that are a result of changes in a firm's information environment when the firm issues new equity. Consistent with this hypothesis they find that firms most likely to suffer from the underinvestment problem, specifically unregulated and private firms with more intangible and less liquid assets are the most likely firms to issue claw back bonds. Similarly Daniels et al. (2009) find that smaller firms with lower ratings and lower profit favor claw back bonds, precisely the kind of firm that will suffer most from the underinvestment problem. They also find that claw back bonds have a higher offering yield spread and therefore are more costly to issuers than ordinary callable bonds.

In summary we find that there is no empirical evidence that ordinary callable bonds deal specifically with the underinvestment problem. However, we find that the theoretical justification for refining the call provision via make whole and claw back clauses is to relieve the underinvestment disincentive. Moreover, the literature claims that these bonds do help resolve the underinvestment problem as firms that issue make whole and claw back bonds are firms that are likely to face underinvestment and after issue enjoy improving growth prospects and stock prices. If indeed make whole and claw back provisions genuinely alleviate the underinvestment disincentive then bondholders as well as shareholders should benefit. Therefore the re-rating experience of 
ordinary callable bonds, that is callable bonds without a make whole or claw back provision, can act as a control sample to detect whether the make whole and claw back provision bonds are dealing more effectively with the underinvestment problem than ordinary callable bonds. Specifically, bonds that contain make whole or claw back provisions should on average experience more upgrades and/or less downgrades than bonds employing ordinary call provisions as subsequent to issue, firms with make whole or claw back provisions should on average have more future investment opportunities that subsequently prove to be valuable to justify the improving growth prospects, higher stock prices and higher credit ratings.

\section{Data selection}

We use the Mergent ${ }^{\circledR}$ Inc's Fixed Investment Securities Database FISD. The FISD consists of detailed cross sectional information on issue characteristics of all bonds that the National Association of Insurance Commissioners had on their books as of January 1, 1995, and all bonds that they bought up to and including May 27, 2008. Each of the approximately 100,000 bond issues is identified by the ISIN number and includes information on the maturity date, offering date, rating date, rating, rating type, offering amount, industry code and type of call provision.

From the FISD, we select all bonds that belong to the industrial, financial, and utility industries while we eliminate Treasury bonds. Therefore our sample contains corporate bonds only. On examining these corporate bonds for rating type we find that Duff and Phelps do not rate many bonds within each rating category. Moreover, virtually all bonds rated by Duff and Phelps are also rated by one of the other mainstream rating agencies, so we decide to neglect Duff and Phelps ratings. However, we consider all Standard and Poor's, Moodys and Fitch rated bonds because they rate a large number of bonds in all industry categories. Of these we only keep those with a rating date within one year of the offering date to ensure that the bond under study has the same rating it had on the date it was offered. Moreover, we cut off the sample selection after May 27, 2007 to 
assure that all bonds in the sample have at least one year of aging so that bond rating agencies have the opportunity to adjust the ratings for the impact of new investment.

To report the characteristics of the sample by rating we convert Standard and Poors, Moodys and Fitch letter ratings into numerical equivalents according to Table 2. Notice that all rating agencies have an almost identical rating system with eight broad rating categories, six of which are sub divided into three shades of ratings. At the lower end there appears to be a minor deviation where Standard and Poors has one lower rating D and Fitch has two additional lower ratings of DD and DDD than Moodys so that in total Moodys has 21, Standard and Poors 22 and Fitch 24 ratings. However this deviation is minor as very few bonds have a rating of D, DD or DDD within one year of issue so we simply assign the same numerical rating of one to Moodys' rating of C, Standard and Poors' ratings of $\mathrm{C}$ and $\mathrm{D}$, and Fitch's ratings of $\mathrm{C}, \mathrm{D}, \mathrm{DD}$ and $\mathrm{DDD}$. Only very few bonds have no rating that we have coded as NR.

\section{$<<$ Table 2 about here $>>$}

Often the rating agencies disagree as to the rating of a bond usually by one shade of credit rating. However, the point of this paper is to determine whether the type of financial contract is able to genuinely resolve the underinvestment problem by examining the change in a given bond's rating over time rather than level of the original rating at the date of issue. Therefore we can avoid issues regarding the rating level when aggregating the sample of Standard and Poors, Moodys and Fitch rated bonds, as we do not have to "average" the ratings of the three agencies. Instead, we take the most recent after issue rating of Standard and Poors, Moodys or Fitch. In the case of "ties" we prioritize Standard and Poors, then Moodys and finally Fitch as these are the rankings of the most common rating agencies on the FISD. 
From this initial selection of bonds we select three sub samples, the make whole, claw back and ordinary callable bond sub samples. The make whole sub sample consists of bonds from the above selection that have make whole call provision but do not contain a claw back provision. Similarly the claw back sub sample consists of bonds that contain a claw back provision but do not contain a make whole provision. Finally ordinary callable bonds have call provisions but do not contain make whole or claw back provisions. We also delete all ordinary callable bonds of firms that have make whole or claw back bonds. This helps ensure that the otherwise callable bond sample can act as a control sample since make whole and claw back provisions are supposed to resolve the underinvestment problem for the firm.

Banko and Zhou (2010) and Crabbe and Helwege (1994) note that the use of call provisions vary through time so to ensure that there is no difference in the trend in the use of make whole, claw back and otherwise callable bonds we plot the number of bonds by offering year and call provision type in Figure 1. This figure shows that prior to the 1995 offering year the database is dominated by otherwise callable bonds except for a single spike of make whole bonds in 1989. In contrast, from 1995 onwards a fairly large number of bonds of each type are issued in each year. As the distribution of offering dates by call provision type is so different prior to 1995 than in subsequent offering years we think that the use of bonds issued prior to 1995 will produce a trend bias to our results so we decided to include only bonds that were offered in 1995 or later in our final sample.

$<<$ Figure 1 about here >>

These selection procedures leave a total sample of 16,612 callable bonds consisting of 5,263 make whole, 3,699 claw back and 7,650 ordinary callable bonds. Tables 3, 4 and 5 report the details of the make whole, claw back and otherwise callable sub samples. 
We make three observations concerning our sample as reported in Tables 3, 4 and 5. First examining the sub samples of bonds by industry, we note that while the make whole and claw back bonds are dominated by the industrial category, the ordinary callable bonds are dominated by the financial industry. Moreover there are few claw back provision bonds in the utility industry. In contrast all types of callable bonds are well represented in the industrial category. Since utility bonds are subject to high regulatory risk that is in large part absent in industrial bonds and the risks associated with financial bonds are different than the risks associated with industrial bonds, we must find a way to control for industry effects so that we are confident that the results will be due to the use of the call provisions rather than differences in industry categories.

Second we examine the sample by credit rating. With the exception of financial bonds, make whole bonds are higher rated and claw back bonds are lower rated than ordinary callable bonds. Specifically, for non-financial bonds the average claw back provision bond has a rating of B and the average make whole call provision bond has a rating of $\mathrm{BBB}+$, slightly more or less than one whole credit rating category lower and higher respectively than the typically BBB- rated ordinary callable industrial bond. It is gratifying to note that except for the very high ratings, AA+ and AA, and for the very low ratings CCC- and below, the granularity of the ordinary callable industrial bond data is very fine. This means that when we refine the sample by broad credit ratings we are able to find a reasonable sample size, at least 35 or more for the ordinary callable industrial bonds, and 139 or more for all ordinary callable bonds to act as a control sample all broad categories of credit ratings.

Third, we examine the sub samples by maturity. We note that ordinary callable bonds and make whole bonds have an average maturity of 15 years and 13 years respectively, which is higher than 9 years average maturity for the claw back provision bonds. However, Bali and Skinner (2006) note that the average maturity of corporate bonds typically declines with credit rating and evidently 
much of this difference in average maturity is accounted for by the differences in average credit rating. For example, examining the average maturity for the $\mathrm{B}$ rating, otherwise callable and make whole bonds typically have a much lower average maturity of 8 to 11 years that is much closer to the 9 years average maturity for the claw back provision B rated bonds. Overall the sample that we select appears capable of providing the data necessary to statistically test to see whether the rerating experience of make whole and claw back provision bonds are different than ordinary callable bonds.

\section{Empirical Results}

Relieving the underinvestment problem should not only improve earnings prospects for the firm but also improve the credit rating of their bonds, as more valuable projects will be accepted. Wider economic events can swamp the positive re-rating effect, but still if these provisions are resolving the underinvestment problem then bonds employing these provisions if not enjoying more upgrade events then they should at least enjoy less downgrade events than otherwise similar ordinary callable bonds.

The literature clearly specifies that call behavior is influenced by bond provisions (e.g. King and Mauer 2000, Mitchell 1991) and listing, bond market and firm effects (e.g. Banko and Zhou 2010, Nayar and Stock 2008, Crabbe and Helwege 1994, Thatcher 1985). Therefore we must control for all of these confounding influences. The FISD contains variables that indicate the presence of the full range of bond covenants including put, conversion and sinking fund features. Additionally the security level is specified in the FISD that we convert to a seven point numerical scale as specified in Table 6 ranking from the highest security level of seven for senior secured bonds to one for the junior subordinate bonds. There are also indicator variables for exchange listing and for private placement of the bond issue. As bond market and firm level data is not available from the FISD we employ two additional sources of information. Bond market information is 
collected from the Federal Reserve Bank of New York, Table H6. We also employ the Q database provided by Capital IQ. The Q database contains financial statement information that can be linked to the FISD bond information via the nine-digit CUSIP numbers. ${ }^{5}$

We are faced with the task of determining whether or not the upgrade and downgrade frequencies for make whole and claw back bonds are different than the upgrade and downgrade frequencies for ordinary callable bonds. This zero, one specification of the investigation naturally leads to a probit model the full specification of which is as follows.

$$
\begin{aligned}
& \mathrm{P}\left(\mathrm{YU}_{\mathrm{i}}=1\right)=\mathrm{F}\left(\text { Constant }+\mathrm{CB}_{\mathrm{i}}+\mathrm{MW}_{\mathrm{i}}+\mathrm{UTL}_{\mathrm{i}}+\mathrm{OCutl}_{\mathrm{i}}+\mathrm{FIN}_{\mathrm{i}}+\mathrm{OCfin}_{\mathrm{i}}+\mathrm{YANKEE}_{\mathrm{i}}+\mathrm{PUT}_{\mathrm{i}}+\mathrm{SF}_{\mathrm{i}}+\mathrm{SL}_{\mathrm{i}}\right. \\
& + \text { Convert }_{\mathrm{i}}+\text { Private }_{\mathrm{i}}+\mathrm{List}_{\mathrm{i}}+\mathrm{MAT}_{\mathrm{i}}+\mathrm{LEVEL}_{\mathrm{i}}+\mathrm{SLOPE}_{\mathrm{i}}+\mathrm{SIZE}_{\mathrm{i}}+\mathrm{DA}_{\mathrm{i}}+\mathrm{CR}_{\mathrm{i}}+\mathrm{CAPrev}_{\mathrm{i}} \\
& +\mathrm{ROA}_{(0)_{\mathrm{i}}}+\operatorname{ROA}(-1)_{\mathrm{i}}+\mathrm{ROA}_{\left.(-2)_{\mathrm{i}}\right)}
\end{aligned}
$$

Where

$\mathrm{YU}_{\mathrm{i}}=1$ if there is an upgrade and 0 if no change in rating within one year of the rating date

$\mathrm{CB}_{\mathrm{i}}=1$ if the bond is a claw back bond, 0 otherwise

$\mathrm{MW}_{\mathrm{i}}=1$ if the bond is a make whole bond, 0 otherwise

$\mathrm{UTL}_{\mathrm{i}}=1$ if the bond is a utility bond, 0 otherwise

OCutl $_{\mathrm{i}}=1$ if the bond is an ordinary callable utility industry bond, 0 otherwise

$\mathrm{FIN}_{\mathrm{i}}=1$ if the bond is a finance industry bond, 0 otherwise

OCfin $_{\mathrm{i}}=1$ if the bond is an ordinary callable financial industry bond, 0 otherwise

$\mathrm{YANKEE}_{\mathrm{i}}=1$ if the bond is a Yankee bond, 0 otherwise

$\mathrm{PUT}_{\mathrm{i}}=1$ if the bond is a putable bond, 0 otherwise

$\mathrm{SF}_{\mathrm{i}}=1$ if the bond is a sinking fund bond, 0 otherwise

$\mathrm{SL}_{\mathrm{i}}=7$ to 1 from the highest to lowest security level as specified in Table 6

Convert $_{\mathrm{i}}=1$ if the bond is a convertible bond, 0 otherwise

\footnotetext{
${ }^{5}$ In performing the match of the Q data with the FISD database we gratefully acknowledge expert help from the staff of Q data. All of the subsequent matches made by CUSIPS were double checked by matching company names.
} 
Private $_{\mathrm{i}}=1$ if the bond is a private placement bond, 0 otherwise

List $_{i}=1$ if the bond is exchange listed, 0 otherwise

MAT $_{i}$ is the at issue maturity of the bond measured in years

LEVEL $_{i}$ is the level of the Treasury term structure as proxied by the one year Treasury interest rate

$\mathrm{SLOPE}_{\mathrm{i}}$ is the slope of the Treasury term structure as proxied by the difference between the ten-year

and one-year Treasury interest rate

$\mathrm{SIZE}_{\mathrm{i}}$ is the log of issuing firm's assets

$\mathrm{DA}_{\mathrm{i}}$ is the debt to assets ratio of the issuing firm

$\mathrm{CR}_{\mathrm{i}}$ is the current ratio of the issuing firm

CAPrev $_{i}$ is the ratio of capital expenditure to revenue of the issuing firm

$\operatorname{ROA}(0)_{\mathrm{i}}$ is the issue year return on assets of the issuing firm

$\operatorname{ROA}(-1)_{\mathrm{i}}$ is the prior year return on assets of the issuing firm

$\operatorname{ROA}(-2)_{\mathrm{i}}$ is the two years prior return on assets of the issuing firm

We will run two sets of probit regressions, the first set above examines the upgrade experience and the second set examines the downgrade experience. Specifically, the second set of probit regressions will be the same as above except that the dependent variable will be YD where one represents a downgrade and zero if there is no rating change within one year of the rating date. These regressions are done in sets that control for the broad rating category of the bond as well as its' investment grade (BBB- and above) and below investment grade (BB+ and below) status.

Industry dummies FIN and UTL control for industry effects. By including dummy variables for both the call provision type and for the industry category, we are also implicitly assuming that the upgrade and downgrade likelihood of the types of call provisions are the same across industries. This may not hold in the case of ordinary callable bonds since Table 5 reveals that ordinary callable bonds have a larger concentration $(76.29 \%)$ in the finance industry than for make whole (Table 2, 
$21.09 \%$ ) and claw back (Table 3, 4.49\%) provision bonds. Moreover, Table 3 reports that claw back provision bonds are almost exclusively industrial (92.73\%) with few financial (4.49\%) and even fewer utility (2.78\%) bonds. It is possible that finance and utility bonds have more (or less) stable ratings than industrial bonds and the difference in industry profile of ordinary callable bonds can taint the interpretation of the call provision $\mathrm{MW}$ and $\mathrm{CB}$ coefficients. ${ }^{6}$ Therefore we include interaction variables OCfin and OCutl for ordinary callable financial and utility bonds respectively and as a result interpret the $\mathrm{CB}$ and MW coefficients as the differential likelihood of a rating change relative to ordinary callable industrial bonds.

Eight variables control for the particular characteristics of a given bond issue. We include the YANKEE dummy variable because foreign bonds can have a different re-rating experience than domestic bonds since they are more exposed to international factors than domestic bonds. Put, sinking fund, security level and conversion feature variables are included because changes in market conditions effect the value of these covenants and therefore could either confound the influence of market conditions on the likelihood of an up or downgrade or directly influence rating agency rating decisions. ${ }^{7}$ We include private placement and exchange listing status as control variables because the presence of make whole and claw back provisions, rather than allowing the stockholders to capture the full value of + NPV projects, could be used by weak credit firms to access financing not otherwise available. In fact Goyal et al (1998) finds that many firms that issue claw back bonds are private firms with low credit ratings, just the sort of firm that can have restrictive access to the public debt market. Finally Barnea et al. (1980) argue that short-term bonds are equally capable of resolving agency problems and information asymmetries as callable bonds so including short-term

\footnotetext{
${ }^{6}$ Indeed evidently it does, as the interaction variables OCfin and OCutl are frequently significant at the $1 \%$ level. Typically the interaction variables report a different re-rating experience than the industrial category. For example, our results show that finance bonds have a higher likelihood of an upgrade than industrial bonds. Without controlling for this interaction effect, we would be comparing claw back bonds that are basically industrial bonds with ordinary callable bonds that are typically financial bonds and likely concluding that claw backs upgrade less frequently than ordinary callable bonds when in fact it is the case that industrial bonds upgrade less frequently than financial bonds.

${ }^{7}$ For example, the decision not to downgrade is a decision that can be influenced by a strong security level provision during a poor economic climate.
} 
bonds without any control for maturity effects can confound the evidence of whether make whole and claw back provisions can resolve the underinvestment problem. Rather than arbitrarily cull our sample for "short term bonds" we choose instead to include bonds of all maturities and include the initial maturity of the bonds MAT as a control variable.

The current level and slope of the term structure of interest rates are summary statistics of the current state of the overall bond market that can influence the likelihood that a given bond can up or down grade. For instance, as the level of the term structure LEVEL rises new projects become more expensive and are less likely to be accepted so the likelihood of an upgrade can decrease. Additionally, Estrella and Hardouvelis (1991) and Estrella and Mishkin (1997) find that an increase in the slope of the term structure foreshadow improvements in real economic activity while Estrella and Mishkin (1998) find that decrease in the slope of the term structure foreshadows recessions. Therefore as the slope of the term structure increases the likelihood that a given bond will upgrade can increase, as economic conditions are more likely to improve. We proxy the level of the term structure as the one year Treasury interest rate and the slope of the term structure as difference between the ten year and the one year Treasury interest rate.

We include seven firm level variables as either control variables or because they can be an alterative explanation for the change in rating of the firm's debt. Firm size is included as a control variable because Goyal et al. (1998) show that the presence of claw back provisions is related to firm size. Bonds can be re-rated for many reasons that are related to the general condition of the firm such as the firm's debt burden, liquidity, growth and profitability. Therefore we include proxies for the issuing firm's debt burden as the ratio of debt to assets DA, liquidity as the current ratio CR, growth as the ratio of capital expenditures to revenue CAPrev and profitability as the firm's return on assets ROA. Moreover a track record of profitability rather than a single year's result could cause a rating change so we include the ROA of the issue year and two years prior to the issue year. 
In summary, equation (1) says that at date $t$, the probability that a given callable bond will upgrade $\left(\mathrm{YU}_{\mathrm{t}}=1\right)$, or maintain its' rating $\left(\mathrm{YU}_{\mathrm{t}}=0\right)$ relative to the base case (ordinary callable industrial bonds) is a function F of a constant, its' call provision (make whole, claw back), industry category (financial, utility), whether the bond is a foreign bond, the presence of covenants (put, sinking fund, security level and conversion features), its' issue status (exchange listed, private placement), the maturity of the bond, the level and slope of the term structure and the characteristics of the issuing firm (size, debt to asset ratio, current ratio, capital expenditures to revenue ratio and current and past profitability). The above equation is estimated via a maximum likelihood probit regression rather than OLS since the dependent variable is dichotomous, only being able to take the value of one or zero. The standard errors are corrected for heteroscedasticity. Table 7 reports the result of (1) for upgrades and Table 8 reports the results of the corresponding regression for downgrades.

\section{$<<$ Tables 7 and 8 about here $>>$}

Looking at the last column, the below investment grade category of Tables 7 and 8, we see that claw back bonds are more likely to upgrade and are less likely to downgrade than ordinary callable bonds. Moreover make whole bonds are more likely to upgrade than ordinary callable industrial bonds. All of these results are statistically significant. Clearly there is strong evidence that below investment grade claw back and make whole bonds have an exceptionally good re-rating experience that persists even when we control for industry, bond market condition, issue and firm characteristics.

In contrast, we are unable to reliably estimate the re-rating experience of investment grade claw back bonds as Table 4 reveals that there are so very few bonds of this type. Additionally, we see that investment grade make whole bonds are more likely to downgrade than industrial ordinary 
callable bonds. Clearly we have no evidence that for the investment grade, claw back and make whole bonds have an unusually good re-rating experience.

These conclusions are reinforced when we examine the re-rating experience by broad rating category. For claw back bonds, we find that B rated bonds, which represents more than $76 \%$ of all claw back bonds, are more likely to upgrade than ordinary callable industrial bonds. Moreover BB rated bonds are less likely to downgrade. Both of these results are highly significant so surely are not due to mere chance. We see that for make whole below investment grade bonds, B bonds are more likely to upgrade. In contrast, the overall downgrade experience for below investment grade make whole bonds is neutral because while $\mathrm{BB}$ bonds are less likely to downgrade, $\mathrm{B}$ rated make whole bonds are more likely to downgrade. Finally we note that A rated make whole bonds are more likely to downgrade and are less likely to upgrade than ordinary callable industrial bonds but as we report above, when aggregated by investment grade category the overall effect is neutral.

Overall we find clear evidence that claw back and make whole bonds do in fact appear to enjoy an exceptionally good re-rating experience but this effect is concentrated in the below investment grade category, just where we would expect agency problems to be most prevalent. We note that these findings are robust to firm and issue characteristics as well as industry effects and bond market conditions. ${ }^{8}$

Next we examine industry effects. Generally speaking, utility bonds UTL seem to have more stable ratings than ordinary callable bonds. Below investment grade utilities are less likely to downgrade and for utilities that are also ordinary callable OCutl they are less likely to upgrade if they are investment grade and are less likely to downgrade if they are below investment grade.

\footnotetext{
${ }^{8}$ We conduct a variety of robustness checks. First, we examine the re-rating experience of make whole, claw back and ordinary callable bonds for the industry category only. Second, we exclude zero coupon and variable rate bonds. We prefer to include zero and variable rate bonds as reported in the text because this increases sample size by 1,763 and it is not clear if the fact that a bond is zero or variable rate it will affect the re-rating experience. Third to check on the stability of the coefficients we split our sample into two equal sized data sets by assigning all even observations in one set and all odd observations in another data set. These results also clearly show that claw back and make whole bonds have a significantly better re-rating experience for the below investment grades. For make whole bonds the investment grade experience proves again to be no different than ordinary callable bonds. These results are not included for the sake of brevity, but are available from the corresponding author upon request.
} 
Financial bonds FIN appear to have a good re-rating experience that is moderated when we examine the performance of financial bonds that are also ordinary callable. Specifically, below investment grade financial bonds FIN are more likely to upgrade and investment grade FIN bonds are less likely to downgrade than ordinary callable industrial bonds. However, when a FIN bond is also an ordinary callable bond OCfin this good re-rating experience is moderated as these bonds are more likely to downgrade and less likely to upgrade, the only exception is for investment grade OCfin where they are more likely to upgrade.

Except for below investment grade bonds, Yankee bonds do not have a different re-rating experience than domestic bonds. For AA and BBB broad rating categories Yankee bonds are either less likely to upgrade or downgrade and B rated bonds are more likely to upgrade than domestic bonds. Aggregating by investment and below investment grades however, the investment grade experience of Yankee bonds is no different than the experience of domestic bonds but the good up grading experience of below investment grade bonds persist.

In most cases bond covenants appear as "sweeteners" to entice bondholder's to invest in them because most types of bonds with covenants tend to have significantly poorer re-rating experience when compared to bonds without these covenants. Convertible investment grade bonds are less likely to upgrade and are more likely to downgrade than nonconvertible bonds. Sinking fund bonds are less likely to upgrade and below investment grade sinking fund bonds are more likely to downgrade than bonds without sinking funds. For the investment grades, the higher the level the security the less likely the bond will upgrade and the more likely the bond will downgrade. For below investment grades, the more security the more unstable the rating as below investment grade bonds with a high level of security are more likely to upgrade as well as downgrade. Only put features are an exception where the put feature is associated with an exceptionally good re-rating experience. Even here however this good re-rating experience apply only for the below investment grade as these bonds are more likely to upgrade than bonds without put features. 
We find that the ratings of issues that are privately placed are more stable, being less likely to upgrade and downgrade for all rating categories. This result is remarkably strong and significant. Meanwhile exchange listed bonds that are also below investment grade are more likely to upgrade and less likely to downgrade. Investment grade exchange listed bonds however, have more unstable ratings being more likely to upgrade as well as downgrade than bonds that are not exchange listed.

Barnea et al. (1980) argue that short-term bonds are equally capable of resolving agency problems as callable bonds so we are also interested to see if the maturity of callable bonds has an effect on the re-rating experience. Interestingly we do find a maturity effect where investment grade bonds are more likely to upgrade and below investment grade bonds are less likely to upgrade with maturity. This is consistent with Barnea et al. (1980) since relatively weak credits do not issue short term bonds and tend to rely on longer term bonds and hence the relatively poor re-rating experience of below investment grade longer term bonds.

We examine the influence of bond market conditions on callable bond re-rating experience. We do not find much evidence that the level or the slope of the term structure affects the re-rating experience of bonds when aggregating the results by investment or below investment grade status. The sole exception is that below investment grade bonds are less likely to downgrade as the level rises. These results suggest that bond-rating agencies make re-rating decisions based on longerterm fundamental factors rather than current bond market conditions, a result that is consistent with Amato and Furfine (2004).

Looking at firm level control variables, we find that the larger the firm the more likely bond issues are to upgrade or downgrade suggesting perhaps that larger firms are more actively monitored by rating agencies. Higher debt burdens foreshadow poor re-rating experience as the higher the total debt to asset ratio DA the less likely a bond will upgrade and the more likely a bond will downgrade. Higher profitability on the other hand foreshadows a good re-rating experience as the higher the current ROA the more likely a bond will upgrade and the less likely a bond will 
downgrade. There appears to be a timing element to the relation between profitability and re-rating experience as prior years return on assets ROA in inversely related to a good re-rating experience. For instance, the higher the profitability one year prior to issue $\operatorname{ROA}(-1)$ the more likely a bond will downgrade and for below investment grade bonds, the less likely they will upgrade. The effect of higher growth on the re-rating experience appears related to the original credit rating. For below investment grade bonds the higher CAPrev the less likely the bond will downgrade but for investment grade bonds the higher CAPrev the less likely to the bond will upgrade. Finally shortterm liquidity when aggregated by investment vs. below investment grade is not related to future rerating experience suggesting that re-rating is related to longer-term structural problems.

\section{Summary and Conclusions}

To date it is not clear whether the make whole and claw back provisions are economically justified. We know from Banko and Zhou (2010) that ordinary calls can alleviate the combination of asymmetric information and underinvestment problems. Other empirical suggests that recent refinements to the call provision, specifically the make whole and claw back call provision, are explained as methods to resolve the underinvestment problem that is already at least partly resolved by ordinary calls. Specifically stockholders appear to benefit from higher earnings and growth subsequent to the issue of make whole provision bonds (Nayar and Stock 2008) and firms that issue claw back bonds are more likely to have problems with underinvestment (Goyal et al.1998). However if these types of callable bonds do in fact alleviate the underinvestment problem, then bondholders should also benefit, otherwise the supposed benefit to the stockholders can represent a repatriation of value already extracted by bondholders with no improvement in the value of the firm. We examine the re-rating experience of callable bonds to see if the re-rating experience of make whole and claw back provision bonds is different from the re-rating experience of ordinary callable bonds. We suggest that if these provisions genuinely confront the underinvestment problem in a 
way that is superior to ordinary call provisions then make whole and claw back provision bonds should share in the benefits from the resolution of the underinvestment problem. Specifically as the firm will be encouraged to accept projects leading to higher growth and earnings, make whole and claw back provision bonds will be more likely to upgrade and/or less likely to downgrade than otherwise similar ordinary callable bonds that do not employ these provisions.

We find evidence that supports this theory for claw back and make whole bonds rated below investment grade, just where agency problems tend to be most severe. Specifically when we control for original rating, industry effects, foreign bond status, bond covenants, listing and maturity effects, economic conditions in the bond market and firm effects such as size, debt burden, liquidity, growth potential and profitability, we find a significantly higher likelihood that below investment grade claw back and make whole bonds will upgrade and a significant lower likelihood that below investment grade claw back bonds will downgrade than ordinary callable bonds. Clearly this suggests that the make whole and claw back refinements to the ordinary call provisions are justified as methods to deal more effectively with the under investment problem at least for bonds that are originally rated below investment grade.

Moreover we find industry effects where financial bonds have a better re-rating experience and utility bonds have a more stable re-rating experience than industrial bonds. Many bond market covenants, specifically the conversion and sinking fund features and the security provision, have a poor re-rating experience suggesting that these sorts of covenants are used as sweeteners to compensate investors for buying risky bonds. Several control proxies suggest that certain types of bonds attract more attention from the rating agencies. Specifically larger firms that list their bonds on an exchange tend to have a more unstable re-rating experience having both a greater likelihood of upgrades and downgrades, as opposed to smaller firms that privately place their bonds that have a stable re-rating experience with a lower likelihood of an upgrade or a downgrade. Rating agencies do not appear to re-rate based on short-term factors such as bond market conditions and the firm's 
liquidity. The firm's current profitability improves but the firm's debt burden deteriorates the bond's re-rating experience while the effect of the firm's growth on the bond's re-rating experience depends upon the grade of the debt. Finally the original maturity of a bond is related to its' re-rating experience where investment grade longer term debt is more likely to upgrade but longer term below investment grade bonds are less likely to upgrade. 


\section{References}

Amato, J. and C. Furfine, 2004, Are credit ratings procyclical? Journal of Banking \& Finance, 28, 26412677.

Bali, G. and F. Skinner, 2006, The original maturity of corporate bonds: The influence of credit rating, asset maturity, security, and macroeconomic conditions, Financial Review 41, 187-203.

Barnea, A., R.A. Haugen, and L.W. Senbet, 1980, A rationale for debt maturity structure and call provisions in the agency theoretic framework, Journal of Finance 35, 1223-1234.

Banko J.C. and L. Zhou, 2010, Callable bonds revisited, Financial Management 39, 613-641.

Bodie, Z. and R.A. Taggart, 1978, Future investment opportunities and the value of the call provision on a bond, Journal of Finance 33, 1187-1200.

Boreiko, D., and S. Lombardo, 2011, Shares' allocation and clawback clauses in Italian IPOs, Journal of International Financial Markets, Institutions and Money 21, 127-143.

Collin-Dufresne, P. and R. Goldstein, 2001, Do credit spreads reflect stationary leverage ratios? Journal of Finance 56, 1929-1957.

Collin-Dufresne, P., R. Goldstein, and J. Spencer Martin, 2001, The determinants of credit spread changes, Journal of Finance 56, 2177-2207.

Crabbe, L.E., and J. Helwege, 1994, Alternative tests of agency theories of callable corporate bonds, Financial Management 23, 3-20.

Daniels, K., D-E. Demissew, and J. Vijayakumar, 2009, An empirical analysis of the determinants and pricing of corporate bond clawbacks, Journal of Corporate Finance 15, 431-446.

Eisdorfer, A, 2011, Why is convertible debt subordinated? Am investment-based agency theory, Financial Review 46, 43-65

Estrella, A. and G.A. Hardouvelis, 1991, The term structure as a predictor of real economic activity, Journal of Finance 46, 555-576.

Estrella, A. and F.S. Mishkin, 1997, Is there a role for monetary aggregates in the conduct of monetary policy?, Journal of Monetary Economics 40, 279-304.

Estrella, A. and F.S. Mishkin, 1998, Predicting U.S. recessions: Financial variables as leading indicators, The Review of Economics and Statistics 80, 45-61.

Fridson, M., 1993, Clawback provisions, Merrill Lynch.

Gottersman, A. and G.S.Roberts, 2007, Loan rates and collateral, Financial Review 42, 401-427. 
Jorion, P. and G. Zhang, 2010, Information transfer effects of Bond rating downgrades, Financial Review 45, 683-706.

Goyal, V. K., Gollapudi, N., Ogden, J.P., 1998, A corporate bond innovation of the 90s: The clawback provision in high-yield debt, Journal of Corporate Finance 4, 301-320.

King, T.-H. D. and D.C. Mauer, 2000, Corporate call policy for nonconvertible bonds, Journal of Business $73,403-444$.

Kish, R. J. and M. Livingston, 1992, Determinants of the call option on corporate bonds, Journal of Banking and Finance 16, 687-703.

Kraus, A., 1973, The bond refunding decision in an efficient market, Journal of Financial and Quantitative Analysis 8, 793-806.

Longstaff, F. and B.A. Tuckman, 1994, Call nonconvertible debt and the problem of related wealth transfer effects, Financial Management 23, 21-27.

Mann, S. V. and E. Powers, 2003a, What is the cost of a make-whole call provision? Journal of Bond Trading and Management 1, 315-325.

Mann, S.V. and E. Powers, 2003b, Indexing a bond's call price: an analysis of make-whole call provisions, Journal of Corporate Finance 9, 535-554.

Mauer, D.C., 1993, Optimal bond call policies under transactions costs, Journal of Financial Research 16, 23-27.

Mitto, U. and Z. Zhang, 2010, Bond market access, credit quality and capital structure: Canadian Evidence, Financial Review 45, 579-602

Nayar, N. and D. Stock, 2008, Make-whole call provisions: A case of "much ado about nothing? Journal of Corporate Finance 14, 387-404.

Powers, E.A. and S. Sarkar, 2008, Setting the optimal make-whole call premiums, University of South Carolina Working Paper.

Powers, E.A. and S. Tsyplakov, 2004, Are make-whole call provisions overpriced? Theory and empirical evidence, Working Paper, University of South Carolina.

Powers, E.A. and S. Tsyplakov, 2008, What is the cost of financial flexibility? Theory and evidence for make-whole call provisions, Financial Management 37, 485-512.

Thatcher, J.S., 1985, The choice of call provision terms: evidence on the existence of agency costs of debt, Journal of Finance 2, 549-561. 


\section{Table 1. Call provision specifications}

This table reports the quantitative details of make whole, claw back and ordinary call provisions of the sample. Note that make whole and ordinary callable bonds have a call protection period where initially the firm cannot make a make whole or an ordinary call for the period of time indicated but a claw back bond can be immediately clawed back. Also effective life is the percentage of the bonds scheduled life where the indicated call provision applies. The claw back percentage refers to the percentage of the original issue that can be clawed back. Finally, claw back and ordinary callable bonds can be called at specified prices whereas make whole bonds are called at the indicated spread over a comparable maturity sovereign bond. NR stands for "not rated".

\begin{tabular}{|c|c|c|c|c|c|c|c|c|c|}
\hline Rating & \multicolumn{3}{|c|}{ Make Whole } & \multicolumn{3}{|c|}{ Claw Back } & \multicolumn{3}{|c|}{ Ordinary Call } \\
\hline & $\begin{array}{l}\text { Call } \\
\text { Prot } \\
\text { (years) }\end{array}$ & $\begin{array}{l}\text { Effective } \\
\text { life }(\%)\end{array}$ & $\begin{array}{l}\text { Spread } \\
\text { (basis } \\
\text { points) }\end{array}$ & $\begin{array}{l}\text { Effective } \\
\text { life }(\%)\end{array}$ & $\begin{array}{l}\text { Claw } \\
\text { Back } \\
\text { Price }\end{array}$ & $\begin{array}{l}\text { Claw Back } \\
\text { Percentage }^{1}\end{array}$ & $\begin{array}{l}\text { Call } \\
\text { Prot } \\
\text { (years) }\end{array}$ & $\begin{array}{l}\text { Effective } \\
\text { life }(\%)\end{array}$ & $\begin{array}{l}\text { Call } \\
\text { Price }^{2}\end{array}$ \\
\hline AAA & 0.11 & 98.18 & 12.26 & NA & NA & NA & 1.65 & 81.85 & 100.07 \\
\hline $\mathrm{AA}$ & 0.19 & 97.60 & 14.45 & NA & NA & NA & 2.97 & 76.84 & 100.30 \\
\hline A & 0.14 & 98.17 & 19.39 & 20.25 & 109.08 & 36.75 & 3.99 & 76.82 & 100.08 \\
\hline BBB & 0.14 & 97.85 & 26.02 & 29 . & 107.83 & 34.33 & 4.18 & 75.43 & 100.39 \\
\hline BB & 0.13 & 96.18 & 43.01 & 32.98 & 108.69 & 34.74 & 4.77 & 63.43 & 102.16 \\
\hline B & 0.08 & 74.39 & 49.56 & 24.83 & 109.75 & 34.75 & 3.87 & 59.02 & 103.11 \\
\hline Below B & 0.45 & 47.71 & 46.67 & 19.32 & 110.56 & 35.70 & 3.00 & 63.40 & 103.07 \\
\hline NR & 0.02 & 99.85 & 23.33 & 33.56 & 111.12 & 35.00 & 4.03 & 79.71 & 100.05 \\
\hline Avg. & 0.14 & 97.07 & 25.80 & 25.20 & 109.71 & 34.86 & 3.67 & 74.63 & 100.55 \\
\hline Obs. & 5,025 & 5,231 & 5,035 & 3,699 & 3,624 & 3,670 & 7,588 & 7,303 & 7,392 \\
\hline
\end{tabular}

${ }^{1}$ There is very little variation in the claw back percentage. Over $80 \%$ of all claw back bonds in our sample can claw back 35\% of the original issue.

${ }^{2}$ Average of initial call price. Also the average does not include the call price of 152 zero coupon bonds as the call price is often far below par. 
Table 2. Standard and Poor's, Moody's and Fitch Numerical Equivalents

This table reports how we assign a numerical rating to Standard and Poors, Moodys and Fitch letter ratings. These numerical ratings are used to measure the average rating by industry, maturity and by bond type.

\begin{tabular}{llll}
\hline S\&P & Moodys & Fitch & $\#$ \\
\hline AAA & Aaa & AAA & 21 \\
AA+ & Aa1 & AA+ & 20 \\
AA & Aa/Aa2 & AA & 19 \\
AA- & Aa3 & AA- & 18 \\
A+ & A1 & A+ & 17 \\
A & A/A2 & A & 16 \\
A- & A3 & A- & 15 \\
BBB+ & Baa1 & BBB+ & 14 \\
BBB & Baa/Baa2 & BBB & 13 \\
BBB- & Baa3 & BBB- & 12 \\
BB+ & Ba1 & BB+ & 11 \\
BB & Ba/Ba2 & BB & 10 \\
BB- & Ba3 & BB- & 9 \\
B+ & B1 & B+ & 8 \\
B & B2 & B & 7 \\
B- & B3 & B- & 6 \\
CCC+ & Caa1 & CCC+ & 5 \\
CCC & Caa2 & CCC & 4 \\
CCC- & Caa3 & CCC- & 3 \\
CC & Ca & CC & 2 \\
C/D & C & C/D/DD & 1 \\
& & /DDD & \\
\hline
\end{tabular}


Table 3. Sample Characteristics of Make Whole Call Provision Bonds

This table reports the sample characteristics of bonds that contain a make whole call provision but does not contain a claw back provision. All bonds are rated by Standard and Poors, Moodys or Fitch within one year of the offering date and have been offered from 1995 to 2007. This sample does not contain government bonds.

\begin{tabular}{|c|c|c|c|c|c|c|c|c|}
\hline & \multicolumn{2}{|c|}{ Industrial } & \multicolumn{2}{|c|}{ Financial } & \multicolumn{2}{|c|}{ Utility } & \multicolumn{2}{|c|}{ Total Sample } \\
\hline Rating & Sample & Maturity & Sample & Maturity & Sample & Maturity & Sample & Maturity \\
\hline AAA & 33 & 19.29 & 13 & 11.17 & 20 & 13.57 & 66 & 15.96 \\
\hline $\mathrm{AA}+$ & 6 & 18.75 & 3 & 21.73 & 4 & 15.01 & 13 & 18.29 \\
\hline $\mathrm{AA}$ & 59 & 16.48 & 32 & 16.01 & 10 & 17.42 & 101 & 16.43 \\
\hline AA- & 71 & 14.28 & 35 & 11.56 & 49 & 19.70 & 155 & 15.38 \\
\hline$A+$ & 203 & 15.52 & 95 & 12.76 & 68 & 15.92 & 366 & 14.88 \\
\hline A & 299 & 15.36 & 90 & 17.39 & 136 & 15.08 & 525 & 15.64 \\
\hline$A-$ & 291 & 12.84 & 121 & 15.41 & 136 & 15.40 & 548 & 14.04 \\
\hline $\mathrm{BBB}+$ & 422 & 14.17 & 182 & 11.77 & 268 & 13.82 & 872 & 13.56 \\
\hline BBB & 582 & 13.21 & 289 & 10.87 & 243 & 13.60 & 1114 & 12.69 \\
\hline BBB- & 422 & 11.98 & 205 & 9.97 & 190 & 13.63 & 817 & 11.86 \\
\hline $\mathrm{BB}+$ & 201 & 10.15 & 25 & 12.37 & 65 & 13.41 & 291 & 11.07 \\
\hline BB & 128 & 8.66 & 9 & 7.80 & 30 & 9.16 & 167 & 8.70 \\
\hline BB- & 62 & 8.78 & 3 & 6.83 & 24 & 8.85 & 89 & 8.73 \\
\hline $\mathrm{B}+$ & 33 & 9.70 & 2 & 22.06 & 12 & 8.14 & 47 & 9.83 \\
\hline B & 35 & 7.92 & 1 & 6.92 & 12 & 9.39 & 48 & 8.27 \\
\hline B- & 21 & 7.57 & 3 & 7.36 & 2 & 10.04 & 26 & 7.74 \\
\hline $\mathrm{CCC}+$ & 10 & 8.71 & 0 & 0.00 & 0 & 0.00 & 10 & 8.71 \\
\hline $\mathrm{CCC}$ & 4 & 8.95 & 0 & 0.00 & 0 & 0.00 & 4 & 8.95 \\
\hline Below CCC & 1 & 6.88 & 0 & 0.00 & 0 & 0.00 & 1 & 6.88 \\
\hline NR & 0 & 0.00 & 2 & 18.53 & 1 & 10.02 & 3 & 15.69 \\
\hline Grand Total & 2,883 & 13.01 & 1,110 & 12.26 & 1,270 & 14.09 & 5,263 & 13.11 \\
\hline Percentage & 54.78 & & 21.09 & & 24.13 & & 100.00 & \\
\hline Avg. Rating & & $B+$ & & $\mathrm{B}+$ & & & & $B_{+}$ \\
\hline
\end{tabular}




\section{Table 4. Sample Characteristics of Claw Back Provision Bonds}

This table reports the sample characteristics of bonds that contain a claw back provision but does not contain a make whole call provision. All bonds are rated by Standard and Poor's, Moody's or Fitch within one year of the offering date and have been offered from 1995 to 2007. This sample does not contain government bonds.

\begin{tabular}{|c|c|c|c|c|c|c|c|c|}
\hline & \multicolumn{2}{|c|}{ Industrial } & \multicolumn{2}{|c|}{ Financial } & \multicolumn{2}{|c|}{ Utility } & \multicolumn{2}{|c|}{ Total Sample } \\
\hline Rating & Number & Maturity & Number & Maturity & Number & Maturity & Number & Maturity \\
\hline A- & 4 & 10.05 & 0 & 0.00 & 0 & 0.00 & 4 & 10.05 \\
\hline BBB- & 3 & 9.94 & 0 & 0.00 & 0 & 0.00 & 3 & 9.94 \\
\hline BB+ & 49 & 8.51 & 2 & 8.52 & 1 & 9.23 & 52 & 8.53 \\
\hline BB & 107 & 8.97 & 16 & 9.52 & 7 & 8.80 & 130 & 9.03 \\
\hline BB- & 241 & 8.78 & 21 & 8.06 & 8 & 9.31 & 270 & 8.74 \\
\hline $\mathrm{B}+$ & 586 & 8.85 & 51 & 8.56 & 16 & 9.30 & 653 & 8.84 \\
\hline B & 887 & 8.90 & 27 & 8.49 & 27 & 8.87 & 941 & 8.89 \\
\hline B- & 1167 & 8.87 & 29 & 8.79 & 29 & 9.24 & 1225 & 8.87 \\
\hline $\mathrm{CCC}+$ & 249 & 8.35 & 18 & 9.33 & 7 & 7.29 & 274 & 8.39 \\
\hline CCC & 91 & 8.52 & 1 & 10.04 & 8 & 8.56 & 100 & 8.54 \\
\hline CCC- & 33 & 7.36 & 1 & 2.64 & 0 & 0.00 & 34 & 7.22 \\
\hline CC & 8 & 7.32 & 0 & 0.00 & 0 & 0.00 & 8 & 7.32 \\
\hline Below CC & 4 & 6.21 & 0 & 0.00 & 0 & 0.00 & 4 & 6.21 \\
\hline NR & 1 & 9.04 & 0 & 0.00 & 0 & 0.00 & 1 & 9.04 \\
\hline Grand Total & 3,430 & 8.80 & 166 & 8.68 & 103 & 8.94 & 3,699 & 8.80 \\
\hline Percentage & 92.73 & & 4.49 & & 2.78 & & 100.00 & \\
\hline Avg. Rating & & 3 & & 3 & & & & 3 \\
\hline
\end{tabular}


Table 5. Sample Characteristics of Otherwise Callable Bonds

This table reports the sample characteristics of bonds of firms that have issued an ordinary callable bond and have not issued a bond that contains a make whole or claw back provision. All bonds are rated by Standard and Poors, Moodys or Fitch within one year of the offering date and have been offered from 1995 to 2007. This sample does not contain government bonds.

\begin{tabular}{|c|c|c|c|c|c|c|c|c|}
\hline & \multicolumn{2}{|c|}{ Industrial } & \multicolumn{2}{|c|}{ Financial } & \multicolumn{2}{|c|}{ Utility } & \multicolumn{2}{|c|}{ Total Sample } \\
\hline Rating & Sample & Maturity & Sample & Maturity & Sample & Maturity & Sample & Maturity \\
\hline AAA & 176 & 11.95 & 212 & 8.76 & 15 & 21.70 & 403 & 10.63 \\
\hline$A A+$ & 1 & 5.02 & 311 & 14.15 & 0 & 0.00 & 312 & 14.12 \\
\hline AA & 6 & 29.03 & 685 & 13.59 & 2 & 35.02 & 693 & 13.79 \\
\hline AA- & 28 & 17.88 & 778 & 11.91 & 7 & 32.84 & 813 & 12.29 \\
\hline$A+$ & 33 & 12.82 & 634 & 16.73 & 16 & 31.28 & 683 & 16.89 \\
\hline$A$ & 389 & 19.41 & 1491 & 15.61 & 21 & 35.14 & 1901 & 16.60 \\
\hline A- & 21 & 18.72 & 468 & 17.78 & 32 & 31.98 & 521 & 18.69 \\
\hline $\mathrm{BBB}+$ & 21 & 21.97 & 284 & 18.03 & 28 & 32.40 & 333 & 19.49 \\
\hline BBB & 47 & 19.64 & 411 & 14.79 & 36 & 25.83 & 494 & 16.06 \\
\hline BBB- & 50 & 19.85 & 287 & 13.88 & 31 & 30.51 & 368 & 16.09 \\
\hline BB+ & 60 & 18.06 & 85 & 15.29 & 17 & 18.28 & 162 & 16.63 \\
\hline BB & 45 & 13.39 & 55 & 13.03 & 5 & 22.29 & 105 & 13.63 \\
\hline BB- & 99 & 12.31 & 23 & 18.44 & 7 & 18.16 & 129 & 13.72 \\
\hline$B+$ & 119 & 10.80 & 31 & 11.30 & 10 & 18.03 & 160 & 11.35 \\
\hline B & 173 & 11.46 & 29 & 11.55 & 6 & 6.60 & 208 & 11.34 \\
\hline B- & 169 & 9.98 & 24 & 12.90 & 3 & 8.12 & 196 & 10.31 \\
\hline $\mathrm{CCC}+$ & 74 & 8.52 & 3 & 4.01 & 0 & 0.00 & 77 & 8.35 \\
\hline CCC & 42 & 9.64 & 4 & 6.81 & 1 & 3.04 & 47 & 9.26 \\
\hline CCC- & 15 & 10.17 & 0 & 0.00 & 0 & 0.00 & 15 & 10.17 \\
\hline CC & 6 & 8.45 & 2 & 5.98 & 0 & 0.00 & 8 & 7.83 \\
\hline Below CC & 2 & 5.19 & 0 & 0.00 & 0 & 0.00 & 2 & 5.19 \\
\hline NR & 1 & 5.01 & 19 & 21.71 & 0 & 0.00 & 20 & 20.88 \\
\hline Grand Total & 1,577 & 14.36 & 5,836 & 14.76 & 237 & 27.29 & 7,650 & 15.06 \\
\hline Percentage & 20.61 & & 76.29 & & 3.10 & & 100.00 & \\
\hline Avg. Rating & & B- & & & & $B+$ & & - \\
\hline
\end{tabular}


Table 6. This table reports the numerical values corresponding to the security level (SL)

\begin{tabular}{ll}
\hline Security Level & $\#$ \\
\hline Senior Secured & 7 \\
Senior & 6 \\
Senior Subordinate & 5 \\
None & 4 \\
Subordinate & 3 \\
Junior & 2 \\
Junior Subordinate & 1 \\
\hline
\end{tabular}


Table 7. Regression Results-UP grades

This table reports the result of the probit regression. YU is a dummy variable where one represents a bond experiencing an upgrade and zero no change at the next re-rating event within one year after issue. MW, CB, OCfin, OCutl, FIN, UTL, YANKEE, PUT, SF, Convert, Private, List are dummy variables where one represents respectively a make whole, a claw back, an otherwise callable, an otherwise callable financial, an otherwise callable utility, a financial, an utility and a Yankee bond, a putable, a sinking fund, a convertible, a privately placed, an exchange listed bond otherwise zero. Moreover SL is the security level of the bond, MAT represents the maturity of a given bond, LEVEL is the one year Treasury yield, SLOPE is the slope of the Treasury yield curve and the Size, DA (debt to assets ratio), CR (current ratio), CAPrev (capital expenditures to revenue ratio) and ROA (return on assets in the issue year and one and two years prior) are variables that represent the characteristics of the issuing firm. The MW and CB coefficients represent the likelihood that the corresponding bond will upgrade relative to the base case of a domestic ordinary callable industrial bond. Standard errors corrected for heteroscedasticity are reported below each coefficient.

\begin{tabular}{|c|c|c|c|c|c|c|c|}
\hline & AA & A & BBB & BB & B & IG & BIG \\
\hline \multirow[t]{2}{*}{ Cons } & -12.810 & 2.096 & -4.304 & -4.600 & -4.438 & -1.626 & -3.482 \\
\hline & 1.335 & 1.406 & 0.953 & 1.258 & 0.065 & 0.733 & 0.750 \\
\hline \multirow[t]{2}{*}{ CB } & N/A & $N / A$ & N/A & -0.518 & $1.053^{\operatorname{xin}}$ & $\mathrm{N} / \mathrm{A}$ & $0.362^{x-x}$ \\
\hline & N/A & $\mathrm{N} / \mathrm{A}$ & $\mathrm{N} / \mathrm{A}$ & 0.321 & 0.070 & $N / A$ & 0.171 \\
\hline \multirow[t]{2}{*}{ MW } & 0.065 & $-0.752^{n \times x}$ & -0.620 & -0.041 & $1.013^{\mathrm{kmx}}$ & -0.193 & $0.405^{x \pi}$ \\
\hline & 3.729 & 0.258 & 0.347 & 0.300 & 0.200 & 0.177 & 0.176 \\
\hline \multirow[t]{2}{*}{ UTL } & $-5.135^{\ldots}$ & 0.110 & 0.508 & 0.266 & 0.175 & 0.202 & 0.075 \\
\hline & 1.566 & 0.240 & 0.185 & 0.175 & 0.176 & 0.133 & 0.108 \\
\hline \multirow[t]{2}{*}{ OCutl } & $-36.429^{\operatorname{xin}}$ & $-4.644^{n \times x}$ & $-5.013^{x \times x}$ & -0.116 & $-4.247^{* x}$ & $-3.759^{m * *}$ & -0.184 \\
\hline & 7.773 & 0.518 & 0.605 & 0.554 & 2.181 & 0.447 & 0.498 \\
\hline \multirow[t]{2}{*}{ FIN } & $-21.670^{\mathrm{xN}}$ & $-0.523^{x *}$ & 0.190 & $1.400^{\mathrm{nx}}$ & $0.459^{* \pi}$ & -0.212 & $0.554^{x \times x}$ \\
\hline & 7.353 & 0.220 & 0.201 & $0.242 \ldots$ & 0.231 & 0.141 & 0.148 \\
\hline \multirow[t]{2}{*}{ OCfin } & 23.884 & $0.747^{-1}$ & 0.403 & $-1.897^{\cdots \cdots}$ & $-1.221^{1 ”}$ & $1.185^{\cdots}$ & $-1.304 \ldots$ \\
\hline & 5.457 & 0.278 & 0.460 & 0.551 & 0.595 & 0.231 & 0.336 \\
\hline \multirow[t]{2}{*}{ YANKEE } & $-50.595^{\mathrm{xx}}$ & 0.080 & $-3.271^{\pi x \pi}$ & 0.091 & $0.782^{n \pi x}$ & 0.060 & $0.522^{x \times x}$ \\
\hline & 15.647 & 0.318 & 0.382 & 0.343 & 0.168 & 0.245 & 0.144 \\
\hline \multirow[t]{2}{*}{ Put } & $-27.640^{\circ \cdots}$ & $-0.821^{\prime \prime}$ & 0.044 & -0.079 & $0.730 \cdots$ & -0.243 & $0.578^{\cdots \cdots}$ \\
\hline & 4.702 & 0.346 & 0.256 & 0.464 & 0.265 & 0.258 & 0.195 \\
\hline \multirow[t]{2}{*}{ SF } & $-56.577^{\prime \prime}$ & -3.200 & -3.015 & $-4.360 \cdots$ & -4.195 & $-3.081^{\cdots}$ & $-4.996 \ldots$ \\
\hline & 7.062 & 0.362 & 0.333 & 0.377 & 2.951 & 0.676 & 0.705 \\
\hline \multirow[t]{2}{*}{ SL } & $-2.836^{\operatorname{mox}}$ & $-0.466^{\operatorname{mox}}$ & -0.018 & $0.865^{x \times x}$ & $0.249^{\operatorname{mox}}$ & -0.168 & $0.279^{\operatorname{mox}}$ \\
\hline & 0.305 & 0.123 & 0.171 & 0.158 & 0.007 & 0.100 & 0.093 \\
\hline \multirow[t]{2}{*}{ Convert } & $-39.011^{\cdots}$ & -0.049 & $-8.193^{\cdots \cdots}$ & 0.117 & $0.856 \ldots$ & -0.880 & 0.119 \\
\hline & 12.199 & 0.358 & 1.169 & 0.456 & 0.169 & 0.410 & 0.228 \\
\hline \multirow[t]{2}{*}{ Private } & $\mathrm{N} / \mathrm{A}$ & $\mathrm{N} / \mathrm{A}$ & $-2.680^{m \times *}$ & $-2.765^{n \times *}$ & $\mathrm{~N} / \mathrm{A}$ & $-2.392^{m \times x}$ & $-4.834^{\mathrm{nox}}$ \\
\hline & $N / A$ & $\mathrm{~N} / \mathrm{A}$ & 0.285 & 0.240 & $\mathrm{~N} / \mathrm{A}$ & 0.777 & 0.699 \\
\hline \multirow[t]{2}{*}{ List } & $20.140^{* x}$ & -0.240 & 0.578 & $-0.435^{* *}$ & $0.256^{* x}$ & $1.061^{\mathrm{mm}}$ & $0.169^{* *}$ \\
\hline & 9.195 & 0.526 & 0.428 & 0.196 & 0.110 & 0.307 & 0.086 \\
\hline \multirow[t]{2}{*}{ MAT } & $0.030^{\cdots}$ & $0.010^{\cdots \cdots}$ & $0.008^{n \prime}$ & $-0.020 \cdots$ & $-0.018 \cdots$ & $0.011^{\cdots \cdots}$ & -0.014 \\
\hline & 0.012 & 0.003 & 0.003 & 0.006 & 0.006 & 0.002 & 0.003 \\
\hline \multirow[t]{2}{*}{ LEVEL } & 0.237 & -0.158 & 0.174 & $-0.330^{x \times x}$ & $0.028^{\operatorname{xix}}$ & 0.037 & -0.088 \\
\hline & 0.320 & 0.100 & 0.102 & 0.121 & 0.009 & 0.050 & 0.051 \\
\hline \multirow[t]{2}{*}{ SLOPE } & $-0.643^{* x}$ & $-0.269^{* *}$ & 0.223 & $-0.421^{x \times m}$ & 0.035 & -0.032 & -0.127 \\
\hline & 0.268 & 0.124 & 0.163 & 0.161 & 0.029 & 0.067 & 0.073 \\
\hline \multirow[t]{2}{*}{ Size } & 0.771 & 0.057 & 0.160 & 0.055 & $0.112^{\cdots}$ & -0.007 & $0.096^{\cdots \cdots}$ \\
\hline & 0.625 & 0.071 & 0.067 & 0.063 & 0.002 & 0.030 & 0.030 \\
\hline \multirow[t]{2}{*}{ DA } & -0.022 & $-0.010^{\mathrm{nax}}$ & -0.008 & $-0.013^{x \times m}$ & $-0.010^{\mathrm{n} \times}$ & $-0.012^{\mathrm{x} x}$ & $-0.004^{n \ldots m}$ \\
\hline & 0.024 & 0.002 & 0.005 & 0.003 & 0.002 & 0.001 & 0.002 \\
\hline \multirow[t]{2}{*}{ CR } & $-0.935^{* x}$ & 0.000 & -0.154 & -0.001 & -0.060 & 0.000 & -0.001 \\
\hline & 0.423 & 0.001 & 0.116 & 0.001 & 0.034 & 0.000 & 0.001 \\
\hline CAPrev & -0.628 & $-0.016 \ldots$ & $-0.015^{\prime \prime}$ & 0.001 & 0.001 & $-0.012 \cdots$ & 0.000 \\
\hline & 0.288 & 0.005 & 0.006 & 0.003 & 0.001 & 0.003 & 0.000 \\
\hline $\mathrm{ROA}(0)$ & -0.171 & $0.202^{\operatorname{xix}}$ & $0.035^{* x}$ & $0.056^{\pi x}$ & 0.020 & $0.060^{\text {xix }}$ & $0.025^{\operatorname{kxx}}$ \\
\hline & 0.142 & 0.040 & 0.017 & 0.023 & 0.013 & 0.022 & 0.009 \\
\hline $\mathrm{ROA}(-1)$ & $2.528^{\circ \cdots}$ & $-0.184^{\cdots \cdots}$ & -0.013 & -0.021 & -0.013 & -0.010 & -0.027 \\
\hline & 0.387 & 0.051 & 0.016 & 0.029 & 0.013 & 0.025 & 0.009 \\
\hline $\operatorname{ROA}(-2)$ & $-2.316^{\ldots \cdots}$ & 0.043 & -0.007 & 0.019 & -0.020 & $-0.058^{\cdots \cdots}$ & -0.009 \\
\hline & 0.528 & 0.033 & 0.021 & 0.018 & 0.008 & 0.021 & 0.006 \\
\hline $\mathrm{N}$ & 715 & 1,748 & 2,291 & 616 & 1,148 & 5,062 & 1,979 \\
\hline
\end{tabular}

**** Significant at the $1 \%,{ }^{* *}$ significant at the $5 \%$ level 
Table 8. Regression Results-Down grades

This table reports the result of the probit regression. YD is a dummy variable where one represents a bond experiencing a downgrade and zero no change at the next re-rating event within one year after issue. MW, CB, OCfin, OCutl, FIN, UTL, YANKEE, PUT, SF, Convert, Private, List are dummy variables where one represents respectively a make whole, a claw back, an otherwise callable, an otherwise callable financial, an otherwise callable utility, a financial, an utility and a Yankee bond, a putable, a sinking fund, a convertible, a privately placed, an exchange listed bond otherwise zero. Moreover SL is the security level of the bond, MAT represents the maturity of a given bond, LEVEL is the one year Treasury yield, SLOPE is the slope of the Treasury yield curve and the Size, DA (debt to assets ratio), CR (current ratio), CAPrev (capital expenditures to revenue ratio) and ROA (return on assets in the issue year and one and two years prior) are variables that represent the characteristics of the issuing firm. The MW and CB coefficients represent the likelihood that the corresponding bond will upgrade relative to the base case of a domestic ordinary callable industrial bond. Standard errors corrected for heteroscedasticity are reported below each coefficient.

\begin{tabular}{|c|c|c|c|c|c|c|c|}
\hline & AA & A & BBB & BB & B & IG & $\mathrm{BIG}$ \\
\hline \multirow[t]{2}{*}{ Cons } & -16.844 & -4.970 & -2.375 & -1.318 & -1.171 & -5.606 & -2.119 \\
\hline & 27.106 & 0.968 & 0.710 & 0.983 & 0.788 & 0.733 & 0.544 \\
\hline \multirow[t]{2}{*}{ CB } & $\mathrm{N} / \mathrm{A}$ & $\mathrm{N} / \mathrm{A}$ & $\mathrm{N} / \mathrm{A}$ & $-0.614 \ldots$ & 0.354 & $\mathrm{~N} / \mathrm{A}$ & $-0.324 \ldots$ \\
\hline & $\mathrm{N} / \mathrm{A}$ & $\mathrm{N} / \mathrm{A}$ & $\mathrm{N} / \mathrm{A}$ & 0.216 & 0.203 & $\mathrm{~N} / \mathrm{A}$ & 0.115 \\
\hline \multirow[t]{2}{*}{ MW } & 0.824 & 1.168 & -0.258 & $-0.704^{m \times n}$ & $0.979^{\times x \times}$ & $0.569^{\sin }$ & -0.233 \\
\hline & 0.551 & 0.164 & 0.340 & 0.222 & 0.281 & 0.107 & 0.135 \\
\hline \multirow[t]{2}{*}{ UTL } & -0.106 & 0.018 & -0.156 & -0.357 & -0.397 & 0.058 & $-0.397^{\cdots \cdots}$ \\
\hline & 0.459 & 0.121 & 0.128 & 0.203 & 0.230 & 0.074 & 0.150 \\
\hline \multirow[t]{2}{*}{ OCutl } & $-2.001^{11}$ & $1.091^{\star n}$ & -0.341 & $-3.593^{\ldots \cdots}$ & $\mathrm{N} / \mathrm{A}$ & 0.315 & $-5.096 \ldots$ \\
\hline & 0.926 & 0.483 & 0.508 & 0.725 & $\mathrm{~N} / \mathrm{A}$ & 0.283 & 0.789 \\
\hline \multirow[t]{2}{*}{ FIN } & -0.225 & -0.307 & $-0.842^{\cdots \times x}$ & 0.224 & 0.084 & $-0.327^{\cdots \cdots *}$ & 0.245 \\
\hline & 0.420 & 0.162 & 0.201 & 0.259 & 0.278 & 0.095 & 0.165 \\
\hline \multirow[t]{2}{*}{ OCfin } & -0.129 & $0.932^{x \times x}$ & $1.091^{* *}$ & $1.397^{\pi \times x}$ & -0.884 & $0.744^{x \times \pi}$ & $1.038^{x \times x}$ \\
\hline & 0.718 & 0.199 & 0.440 & 0.379 & 0.869 & 0.142 & 0.252 \\
\hline \multirow[t]{2}{*}{ YANKEE } & -0.324 & 0.087 & $-4.112^{\cdots \cdots}$ & 0.234 & 0.157 & 0.007 & -0.119 \\
\hline & 0.699 & 0.225 & 0.633 & 0.377 & 0.216 & 0.131 & 0.192 \\
\hline \multirow[t]{2}{*}{ Put } & 0.674 & -0.036 & -0.196 & -0.860 & 0.164 & 0.002 & -0.201 \\
\hline & 0.465 & 0.258 & 0.401 & 0.463 & 0.259 & 0.202 & 0.200 \\
\hline \multirow[t]{2}{*}{ SF } & -24.842 & 0.128 & $-2.969^{\cdots}$ & 0.543 & $-3.653^{\ldots}$ & 0.355 & $0.729 "$ \\
\hline & 29.415 & 0.329 & 0.439 & 0.516 & 1.209 & 0.378 & 0.367 \\
\hline \multirow[t]{2}{*}{ SL } & -0.415 & 0.188 & $0.421^{\cdots \cdots}$ & $0.223^{\prime \prime}$ & 0.047 & $0.248^{\cdots \cdots}$ & $0.143^{\prime \prime}$ \\
\hline & 0.480 & 0.121 & 0.155 & 0.106 & 0.094 & 0.091 & 0.066 \\
\hline \multirow[t]{2}{*}{ Convert } & $4.154^{* \pi x}$ & $0.933^{* \pi}$ & $1.122^{\text {xxx }}$ & -0.366 & $0.789^{\operatorname{sxx}}$ & $0.854^{\pi \times x}$ & -0.252 \\
\hline & 1.314 & 0.396 & 0.392 & 0.409 & 0.255 & 0.271 & 0.178 \\
\hline \multirow[t]{2}{*}{ Private } & $\mathrm{N} / \mathrm{A}$ & $\mathrm{N} / \mathrm{A}$ & $-3.273^{\ldots n}$ & $\mathrm{~N} / \mathrm{A}$ & -3.310 & $-3.488^{\ldots \prime}$ & $-4.797 \ldots$ \\
\hline & $\mathrm{N} / \mathrm{A}$ & $\mathrm{N} / \mathrm{A}$ & 0.463 & $\mathrm{~N} / \mathrm{A}$ & 1.358 & 0.172 & 0.750 \\
\hline \multirow[t]{2}{*}{ List } & 13.123 & 0.023 & 0.174 & -0.198 & -0.266 & $0.209^{\mathrm{xN} x}$ & $-0.229^{x \times x}$ \\
\hline & 23.778 & 0.117 & 0.113 & 0.136 & 0.091 & 0.059 & 0.066 \\
\hline \multirow[t]{2}{*}{ MAT } & -0.003 & -0.003 & -0.008 & $0.014^{x \times x}$ & $-0.015^{n \times m}$ & -0.003 & 0.004 \\
\hline & 0.008 & 0.002 & 0.002 & 0.005 & 0.006 & 0.002 & 0.003 \\
\hline \multirow[t]{2}{*}{ LEVEL } & $0.680^{\circ}$ & $0.139^{\circ}$ & $-0.322 \cdots$ & -0.055 & -0.068 & 0.040 & -0.106 \\
\hline & 0.166 & 0.044 & 0.058 & 0.084 & 0.069 & 0.029 & 0.045 \\
\hline \multirow[t]{2}{*}{ SLOPE } & $0.615^{x \times}$ & $0.170^{\mathrm{xax}}$ & $-0.599^{* \ldots *}$ & 0.084 & 0.017 & 0.016 & -0.005 \\
\hline & 0.252 & 0.061 & 0.090 & 0.125 & 0.101 & 0.040 & 0.065 \\
\hline \multirow[t]{2}{*}{ Size } & 0.178 & 0.039 & -0.034 & -0.053 & 0.000 & $0.120^{\mathrm{x} \times x}$ & $0.099^{x \times x}$ \\
\hline & 0.134 & 0.035 & 0.044 & 0.061 & 0.041 & 0.022 & 0.028 \\
\hline \multirow[t]{2}{*}{ DA } & 0.001 & 0.018 & $0.021^{\cdots}$ & $0.009^{\prime \prime}$ & 0.003 & $0.016^{\ldots \prime}$ & $0.003^{\cdots \cdots}$ \\
\hline & 0.006 & 0.002 & 0.003 & 0.004 & 0.002 & 0.001 & 0.001 \\
\hline \multirow[t]{2}{*}{ CR } & $-0.820 \times$ & $0.003^{\text {xix }}$ & $-0.384^{n \times x}$ & -0.018 & $-0.200^{x \times x}$ & 0.000 & -0.018 \\
\hline & 0.354 & 0.001 & 0.090 & 0.033 & 0.055 & 0.000 & 0.012 \\
\hline CAPrev & 0.008 & -0.002 & $0.005^{\ldots \cdots}$ & -0.002 & $-0.007^{\cdots \cdots}$ & -0.001 & $-0.003^{m}$ \\
\hline & 0.006 & 0.001 & 0.001 & 0.002 & 0.002 & 0.000 & 0.001 \\
\hline $\mathrm{ROA}(0)$ & -0.105 & $-0.177^{\cdots \cdots}$ & $-0.066^{\ldots \cdots}$ & $-0.102 \cdots$ & $-0.078^{\cdots \cdots}$ & $-0.077^{\prime \prime}$ & $-0.066^{\cdots \prime}$ \\
\hline & 0.066 & 0.029 & 0.021 & 0.020 & 0.012 & 0.013 & 0.008 \\
\hline $\mathrm{ROA}(-1)$ & $0.323^{\mathrm{x} x}$ & 0.064 & $0.024^{\pi *}$ & 0.023 & $0.022^{x *}$ & $0.039^{\sin }$ & $0.026^{\times x x}$ \\
\hline & 0.104 & 0.041 & 0.012 & 0.026 & 0.011 & 0.011 & 0.009 \\
\hline $\mathrm{ROA}(-2)$ & $-0.306^{n \times x}$ & $0.071^{* \pi}$ & 0.003 & -0.020 & 0.009 & $0.035^{\mathrm{knx}}$ & $0.012^{x \times x}$ \\
\hline & 0.108 & 0.031 & 0.017 & 0.016 & 0.005 & 0.011 & 0.005 \\
\hline $\mathrm{N}$ & 500 & 2101 & 2525 & 670 & 1219 & 5,458 & 2,071 \\
\hline
\end{tabular}

**** significant at the $1 \%, *$ significant at the $5 \%$ level 
Figure I:Offering year distribution by call provision type This graph reports the number of claw back, make whole and ordinary callable bonds by year of issue

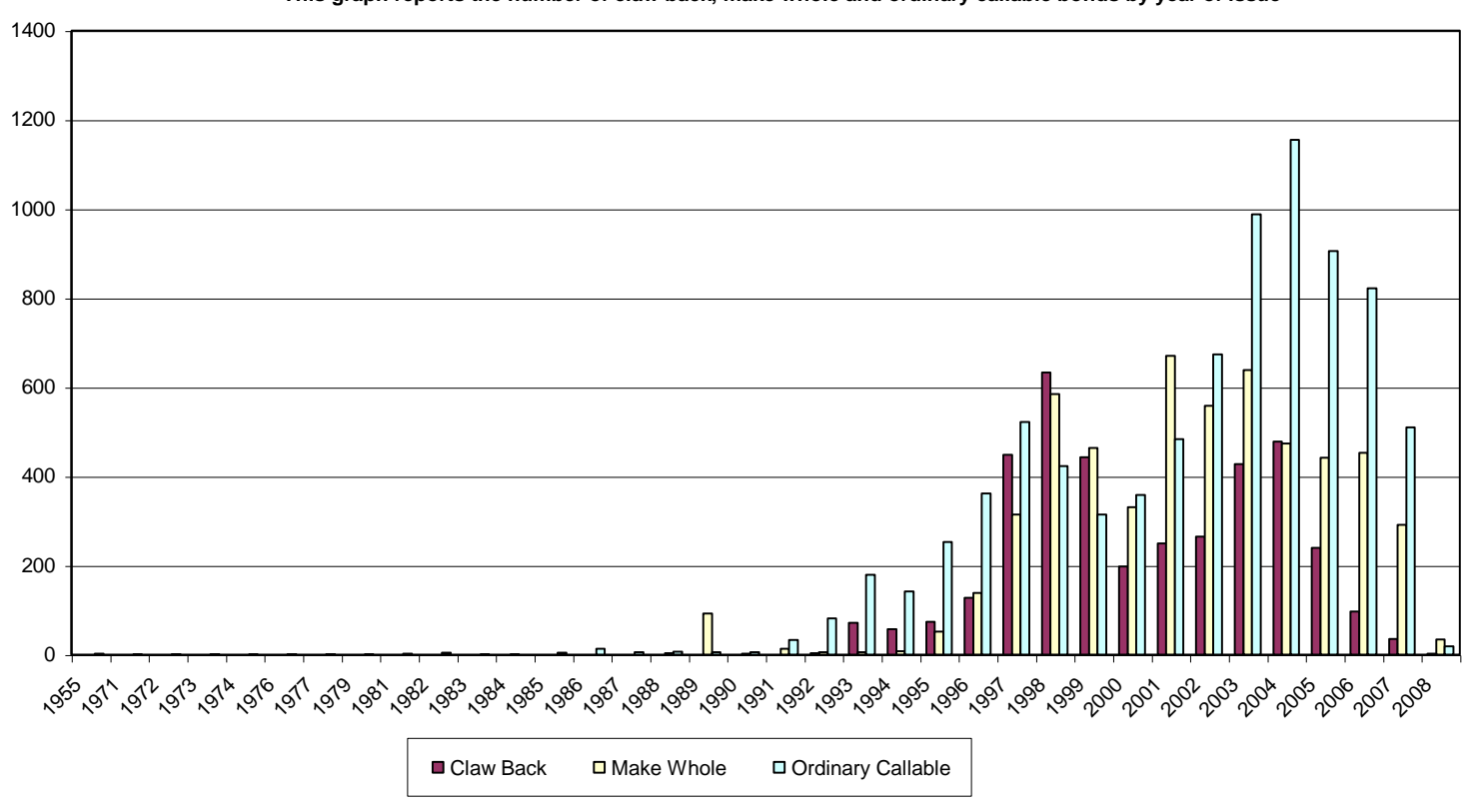

